TAZKIYA (Jurnal of Psychology)

DOI: http://dx.doi.org/l0.15408/tazkiya.v9i2.21699

http://journal.uinjkt.ac.id/index.php/tazkiya

\title{
Program Evaluation of A Community-Based Drug Rehabilitation Center: The Perspectives of The Persons Who Use Drugs (PWUDs)
}

\author{
Argel B. Masanda ${ }^{1}$, Gino A. Cabrera ${ }^{2}$, Alain Bernard A. Andal ${ }^{3}$, Clarissa F. Delariarte ${ }^{4}$, \\ Gil Jeff S. Tanganco ${ }^{3}$, and Alyana Fae R. Balbuena ${ }^{5}$ \\ ${ }^{1}$ Central Luzon State University, ${ }^{2}$ Southern Luzon State University, ${ }^{3}$ Holy Angels University, \\ ${ }^{4}$ Far Eastern University, and ${ }^{5}$ University of Perpetual Help System DALTA
}

argelmasanda@,clsu.edu.ph

\begin{abstract}
Bahay Pagbabago ni Apong Pilar is a community-based, church-initiated, and DDB (Dangerous Drugs Board) recognized and accredited formation shelter in San Simon, Pampanga. Using the sequential explanatory design, this study conducted surveys and focused-group discussions with 32 reformists to assess the shelter's formation program based on the reformists' standpoints. Quantitative results using Spearman's rank correlations showed that there seemed to be a significant relationship between attitude towards livelihood $\left(\rho(2)=6.589\right.$, sig. $\left.=0.037^{*}, \mathrm{p}<0.05\right)$ and spiritual activities $\left(\rho(27)=0.587^{* *}, \mathrm{p}<0.01\right)$, as formative components of the program, and perceived self-improvement $\left(\rho(2)=13.573\right.$, sig. $\left.=0.001^{* *}, p<0.01\right)$ during their stay in the formation shelter. It suggests that as the reformist develops a more positive attitude towards the livelihood, sports, and spiritual activities being offered at the formation center, it is also more likely that they may develop a higher sense of self-improvement. Qualitative data yielded three general themes: (1) finding a higher purpose and deeper meaning in life through spiritually uplifting undertakings; (2) having familyoriented treatment, making them feel nothing less of their humanity; and (3) having holistic and dynamic activities, those that focus on the developmental facets. These are the elements deemed by the reformists as important, which constitute effective reintegration to their families, communities, and society.
\end{abstract}

Keywords: Program, Evaluation, Rehabilitation, Drug Reformists

\begin{abstract}
Abstrak
Bahay Pagbabago ni Apong Pilar adalah tempat penampungan yang diinisiasi oleh gereja, dan DDB (Badan Penanggulangan Bahaya Narkoba) yang diakui dan terakreditasi di San Simon, Pampanga. Dengan menggunakan desain penjelasan sekuensial, studi ini melakukan survei dan diskusi kelompok terfokus dengan 32 peserta program untuk menilai program pembentukan shelter berdasarkan sudut pandang peserta. Hasil analisa kuantitatif dengan menggunakan korelasi Spearman menunjukkan bahwa tampak ada hubungan yang signifikan antara sikap terhadap mata pencaharian $\left(\rho(2)=6,589\right.$, sig. $\left.=0,037^{*}, p<0,05\right)$ dengan aktivitas spiritual $\left(\rho(27)=0,587^{* *}, p<0,01\right)$, sebagai komponen formatif program, dan perbaikan diri yang dirasakan $\left(\rho(2)=13,573\right.$, sig. $\left.=0,001^{* *}, p<0,01\right)$ selama mereka tinggal di penampungan. Ini menunjukkan bahwa peserta diharapkan mengembangkan sikap yang lebih positif terhadap mata pencaharian, olahraga, dan kegiatan spiritual yang ditawarkan di pusat formasi, juga lebih mungkin bahwa mereka dapat mengembangkan rasa perbaikan diri yang lebih tinggi. Data kualitatif menghasilkan tiga tema umum: (1) menemukan tujuan hidup yang lebih tinggi dan makna yang lebih dalam melalui upaya-upaya peningkatan spiritual; (2) mendapatkan treatment yang berorientasi pada keluarga sehingga membuat mereka merasa seperti layaknya manusia; dan (3) memiliki kegiatan yang holistik dan dinamis, yang berfokus pada aspek perkembangan. Inilah unsur-unsur yang dianggap penting oleh peserta, yang merupakan reintegrasi yang efektif kepada keluarga, komunitas, dan masyarakat mereka.
\end{abstract}

Kata kunci: Program, Evaluasi, Rehabilitasi, Survivor dari penyalahgunaan zat. 
TAZKIYA (Journalof Psychology), 9(2), 2021

\section{Introduction}

One of the global pandemics among the myriad burden of disease that we face is the substance use problem. Indeed, substance abuse has resulted in being a massive burden of society - not limited to the users' personal life and significantly affected the quality of life of their families and ultimately the functioning of an ideal society $(\mathrm{Wu}, 2010)$. In the Philippines, the Philippine Dangerous Drugs Board (DDB, 2015) estimated 1.8 million substance users. However, in 2016 total reported cases of substance users accommodated in rehabilitation facilities are only 6,079 individuals. According to Ramos (2017), there are only 50 governmentrecognized facilities for substance users and abusers. With the immediate goals of the Philippines' "war on illegal drugs" implemented in 2016, one of the unforeseen consequences of this battle is the displacement of the hundreds of thousand drug surrenderers - expected for rehabilitation. Despite the government's hope to eradicate the country's drug problem, on the other hand, there was an evident shortage of interventions to provide the substance users the services they need to recover and reform.

Moreover, the limited intervention programs have motivated different public and private sectors to help rehabilitate the victims of substance abuse. For example, in San Simon, Pampanga, among the recognized facilities of the DDB, is the Bahay Pagbabago ni Apong Pilar. It is a community-based formation center initiated by the Catholic Church that offers an in-house program to reform individuals in the neighboring communities who seek asylum to overcome substance use and abuse through a spiritual approach. The Bahay Pagbabago ni Apong Pilar formation center's program aims to cater to the substance users (reformists) through nurture and care to rediscover human dignity, be productive individuals, and become value-oriented individuals through the collaborative efforts of the facility's volunteers as inspired by the Church's teachings. The program attempts to reform the substance users by engaging mainly in spiritual activities designed to cater to holistic transformation, with other activities such as livelihood skills development and sports activities.

Since the 1980s, publications focusing on the meaning, definition, and assessment of spirituality began to emerge in health-related literature (Paal, Helo, Frick, 2015). For example, Chandler, Holden, \& Kolander (1992) stated that "spiritual" refers not only to experiences traditionally considered religious but to all the state of awareness, all the human functions, and activities which have a common denominator: the possession of values higher than average. According to Poll \& Smith (2003), the sense of spiritual identity, an individual's belief that she or he is an eternal being and connected to God, is an aspect of human spirituality thought to protect and restore psychological health effects. Poll \& Smith also stated that research indicates that mental health may be promoted through spiritual means.

The community represents another critical component in the rebuilding process (Hoffman, 2016). Today, almost all countries need to consider how best to respond to the abuse of one or more psychoactive substances that are causing problems for individuals, families, and communities (United Nations Office on Drugs and Crime, 2002). Hoffman emphasized that the community provides the environment "where we can practice honesty and humility, and where we can give and receive gifts of strength and hope." Moreover, he also stated that participating in community reminds individuals that they do not face their spiritual brokenness alone. In the context of community, one person's story intersects with another individual's story. According to Whitley \& Drake (2010), they may come to see their recovery as depending on finding a spiritual path or becoming part of a religious or spiritual community. In the community context, the forgiveness of sins is realized, and the best rebuilding of damaged spiritual lives occurs. Hoffman also added that one heals and recovers most fully in the context of community. According to Grandisson, Thibeault, Hebert, \& Templeton (2014), the main lessons learned about community-based rehabilitation program evaluation are associated with strategies to 1) foster active participation, 2) collect accurate and credible information, 3) build local capacity, and 4) foster sustainable partnerships. Time spent to promote a positive learning spirit and participatory tools with all groups appeared critical to active engagement in evaluation activities. While it is possible to develop a single treatment program or an entire treatment system without such a framework, there are substantial benefits in establishing one (United Nations Office on Drugs and Crime, 2002). In contrast, the World Council of Churches (2001) argued that the importance of community- 
based rehabilitation programs could not be over-emphasized, especially in settings where a large majority have no way out of their misery, hardship, and discrimination.

Further, an array of literature tackled how spiritual activities are applicable in clinical practice and healthcare professionals. According to Paal, Helo, \& Frick (2015), healthcare professionals have a genuine interest in providing spiritual care and building a relationship with their patients. Scholars, health practitioners, policymakers, and healthcare recipients increasingly recognize the influence of spirituality on health and the importance of considering the spiritual dimension in providing health care services (Chiu, Emblen, Hofwegen, Sawatzky, \& Meyerhoff, 2004). The central aim of spiritual care is "to offer a framework for healthcare professionals to connect with their patients, listen to their fears, dreams, and pain; collaborate with their patients as partners in their care; and provide, through the therapeutic relationship, an opportunity for healing" (Paal et al., ). Galek, Flanelly, Vane, \& Galek (2005) also emphasized that only through acquiring a better understanding of patients' spiritual needs will professionals develop tailored and effective spiritual interventions. Concerning mental health, Poll \& Smith (2003) also added that professional counselors and psychotherapists are demonstrating increasing interest in the spiritual lives of their clients, recognizing the importance of addressing spirituality in therapy. Poll \& Smith also stated that mental health might be promoted through spiritual means.

In terms of substance user's self-improvement towards spiritual activities, Miller, Forcehimes, O'Leary, \& Lanoue (2009) stated that spirituality has long been regarded as an essential component of recovery from addiction. However, Miller et al. emphasized that people entering addiction treatment sometimes show low spiritual/religious involvement relative to the general population. According to Hoffman (2016), addiction contributes to disconnection and disorientation due to the disloyalty and disinclination of one's heart and entire life away from centralization in God. When an individual is arrested for an alcohol or other drug offense for the first time, it precipitated a crisis of faith, and many questions fill the quiet moments while sitting in the back seat of a law enforcement vehicle or a holding cell of a municipal or county jail. According to the World Council of Churches (2001), drug addicts, as a rule, reject 'outsiders' and tend to be reclusive, but because of this initiative, some of them started to talk and share their problems, which in turn made them open to accepting help. It paved the way to introduce a change of attitude toward life and slowly encouraged them to sign up for help with rehabilitation. The World Council of Churches also added that since drugs destroy them physically and condemn them to a life of anguish, rejection, and loneliness, the importance of support and encouragement to help them break free from this vicious setup was underlined. Many of those who come for treatment do so because they have "hit bottom" and describe this feeling as one of destruction, having lost everything, being nobody, losing respect for their own families to the extent of stealing from them or hurting them.

Chandler, Holden, \& Kolander (1992) emphasized that "spiritual transformation" included personality changes such as greater authenticity, the actualization of inner potentials, and positive concepts. Paal, Helo, \& Frick (2015) also added that spiritual care is person-centered care that seeks to help people (re)discover hope, resilience, and inner strength in illness, injury, transition, and loss. In contrast, according to Ramos (2017), it has been utilized in the Philippines for decades as an approach in treatment facilities for individuals with substance use disorders. However, it falls short in providing continuous support for the challenging and lifelong struggle towards full recovery. Ramos (2017) also argued that despite the influx of both public and private institutions catering to patients with substance use disorder all over the country, existing interventions seem to be insufficient in reaching out to the population suffering from the condition.

The concept that religion and spirituality are relevant to clinical practice and are much of a person's orientation to life as their ethnicity, gender, and culture are becoming a standard within the therapeutic community and over the past years, integrating religion and spirituality into clinical practice has been typical (Eck, 2002). According to Miller, Forcehimes, O'Leary, \& Lanoue (2009), religious involvement is inversely related to the prevalence of substance use, abuse and dependence, both concomitantly and prospectively. Haque (2000) argued that historically speaking, psychology and religion have worked separately to improve mental health among people. Haque's literature review shows that 11 out of 12 studies reporting a negative relationship between religion and substance abuse. Haque also indicated that attending a church is a more 
powerful factor in preventing a person from abusing substances rather than having a "religious feeling" about the situation. In contrast, Eck stated that religious practice is quite pervasive in the United States. Several studies of Americans report that they believe in God, 93\% identify with a religious group, 88\% report they pray, and $87 \%$ report that God answers prayers (apparently one percent pray but do not believe that God answers prayers).

This study served as one of the preliminary evaluations of a church-initiated program for substance users and abusers that aims to report the different perspectives of the reformists, to describe and further explain their views on the Bahay Pagbabago ni Apung Pilar's program. In addition, it sought to answer the following questions:

1. What are the attitudes of the drug reformists towards the activities provided by the formation center?

a. Is there a significant difference in the drug reformists' attitude towards the activities in the formation center when grouped according to their sex and age?

b. Is there a significant difference in the drug reformists' self-improvement in the formation center when grouped according to sex and age?

c. Is there a significant relationship between the drug reformists' perceived self-improvement and their attitude towards the formation house's activities?

2. How do the respondents describe their self-improvement in the formation center?

a. What are the factors that contribute to their improvement in the formation center?

b. What are the factors that hinder their improvement in the formation center?

c. What makes a good drug rehabilitation program based on their experiences in the formation center?

In the Philippines, the most commonly used treatment approaches have not been evaluated or continue to be used despite the little evidence of their effectiveness, and program evaluation has not played a significant role in shaping rehabilitation services. Primarily Program planners and decision-makers have relied only on personal experiences and opinions rather than on scientific data (Rush, 2003). On the other hand, Leahy et al. (2009) emphasized the essential role of quality assurance mechanisms such as program evaluation in the continuous improvements in rehabilitation services. Therefore, there is a need to be anchored in a program theory or a logic model. This study followed the three components of program theory modeling according to Sharpe (2011): program activities or inputs, mechanisms through which the intended outcomes are achieved, and the intended outcomes or outputs.

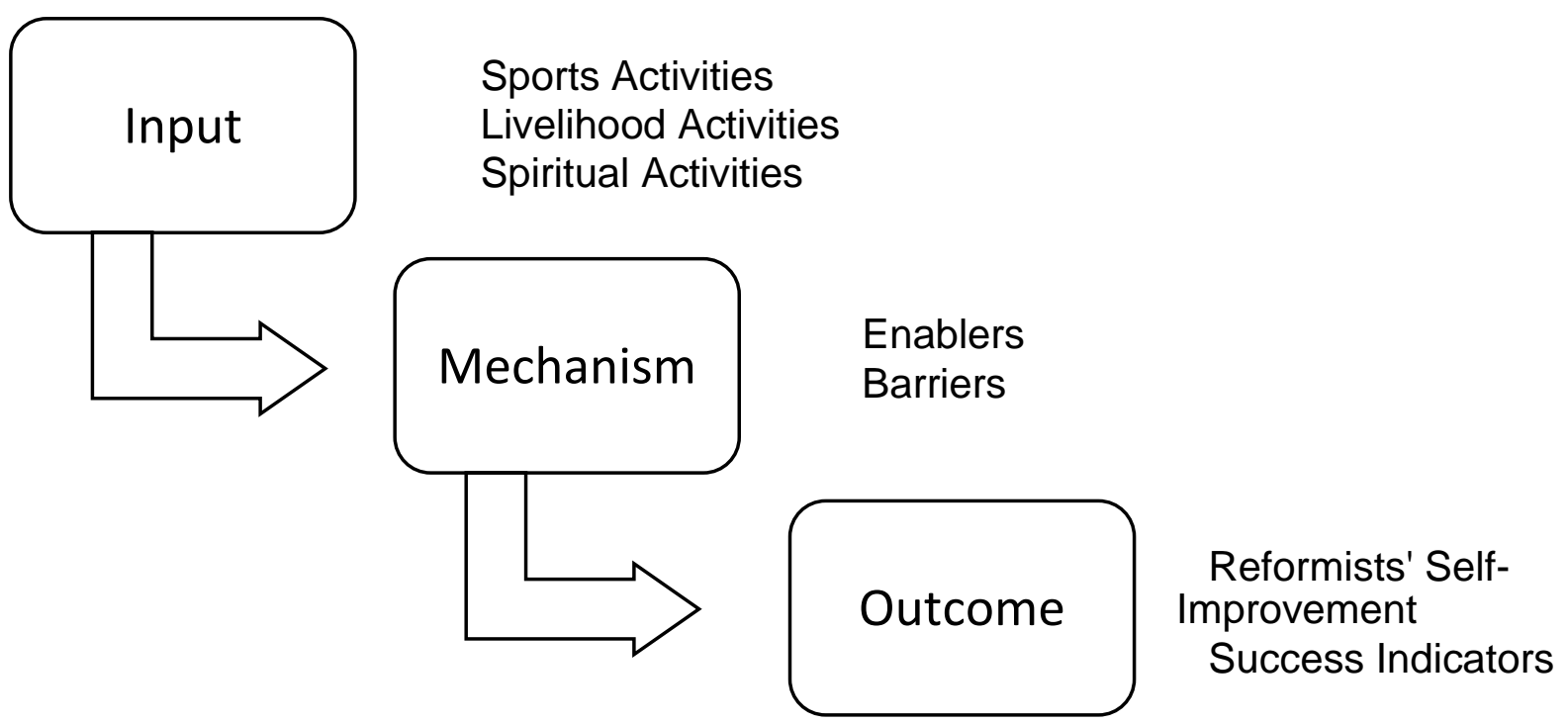


As a preliminary evaluation of a church-initiated program for former drug users that aims to report the different perspectives of the drug reformists, the study shall serve as a supplement with the existing program to further improve and develop the valuable reforming program. Therefore, it is pivotal to review the program to establish success indicators and identify its limitations. Furthermore, it shall direct the program planners and implementers on what rehabilitative components should be added, how much resources should be allocated, or how they should capacitate the program facilitators to be more skillful.

\section{Method}

The study used a mixed-method research design-Sequential Explanatory-to corroborate the quantitative and qualitative data collected from the Bahay Pagbabago ni Apung Pilar reformists. This research design is a two-phase method where the quantitative data is collected first, followed by qualitative data. Further, causal-comparatives was used to compare the respondent reformists' perceived attitude towards the activities and their self-improvement in the formation center when grouped according to their gender and age.

Participants for this study are all the 27 reformists housed at Bahay Pagbabago ni Apung Pilar, San Simon, Pampanga. Twenty-four of them are male, while only three are female. In terms of age group, 12 are between 31 to 40 years old while eight are below 30. Only seven of them are above 40 years old.

\section{Quantitative Measures}

- A self-made Formation House Attitude towards Activities scale was developed. The scale seeks to measure the reformists' agreeableness in the conduct of three identified activities, namely: Sportsfest $(\mathrm{N}=10)$, Livelihood $(\mathrm{N}=10)$, and Spiritual $(\mathrm{N}=10)$. Cronbach's Alpha test shows that the total activity scale has a high internal consistency $(\mathrm{alpha}=0.946)$. Meanwhile, the sub-scales show moderate to high internal consistency (Livelihood, alpha $=0.769$, Spiritual, alpha $=0.769$ and Sports, alpha $=0.907$. The said test is a 7-point Likert scale with descriptions ranging from $(1=$ Extremely Disagree, $2=$ Moderately Disagree, 3= Slightly Disagree, 4= Neutral, 5= Slightly Agree, 6=Moderately Agree, and 7= Extremely Agree).

- To measure the perceived self-improvement of the respondent reformists, a Formation House Improvement Scale was also developed. This scale consists of 12 items with a five-point Likert scale format, with a Cronbach's alpha $=0.65$ or 0.70 . Thus, the scale has a moderate level of internal consistency.

\section{Qualitative Measures}

- Semi-structured interview guide 1 focused on the reformists' views on the formation center's mission, vision, and core values. The instrument has nine open-ended questions, two for general views on the formation house's mission, vision, and core values; three questions focused on the mission; two for the center's vision; and three questions about core values.

- Semi-structured interview guide 2 consisted of 18 questions to capture and find meaning from the perspective of the reformists upon their experience of the formation program.

Upon the conceptualization of this study, approval was sought from the Bahay Pagbabago ni Apung Pilar administrators to permit the researchers to conduct a study that involves the reformists of the said formation center. Solicitation of informed consent and letter of participation to all drug reformists ere then followed. All of the reformists willingly volunteered to participate in the study. The interview was audiorecorded with the consent of every participant. All pertinent research-related ethics were strictly observed.

The study has two phases of analysis. First - the quantitative part, the study used descriptive statistics through mean and standard deviation to measure the attitude towards the activities and the perceived selfimprovement of the respondents. Non-parametric statistics through Kruskal-Wallis, Mann-Whitney, and Spearman Rho were also utilized. 
For the qualitative part, thematic analysis was utilized as a general mode of analysis rather than a singular one. It emphasizes pinpointing, examining, and recording patterns (or "themes") within data gathered from the focused-group discussion. More specifically, the phases performed are the following: familiarization with data, generating initial codes, searching for themes among codes, reviewing themes, defining and naming themes, and finally producing the final report

\section{Results and Discussion}

\section{Quantitative Phase}

The table below indicated the drug reformists' overall feelings, beliefs, and behaviors related to the formation house's activities.

Table 1.

Drug reformists' attitude towards the formation house's activities.

\begin{tabular}{clccl}
\hline \multicolumn{2}{c}{ Formation House's Activities } & Mean & SD & \multicolumn{1}{c}{ Description } \\
\hline Sports & & 5.78 & 0.87 & High \\
& Livelihood & 5.45 & 0.73 & High \\
& & 5.86 & 0.77 & High \\
\hline Spiritual & & & $4.41-5.25$ & High Average \\
& $1.00-1.85$ & Very Low & $5.26-6.10$ & High \\
& $1.86-2.70$ & Low & $6.11-7.00$ & Very High \\
& $2.71-3.55$ & Low Average & &
\end{tabular}

These results showed that the Bahay Pagbabago ni Apong Pilar drug reformists considered all of its activities to have a "high" impact on their overall formation experiences. Hence, they see sports, livelihood, and spiritual activities as all equally important to their causes.

On the other hand, table 2 below indicated their perceived self-improvement based on their experiences in the formation house's activities.

Table 2

Drug reformists' perceived self-improvement inside the formation house.

\begin{tabular}{lclclc}
\hline & Scale & & Mean & SD & \multicolumn{1}{c}{ Description } \\
\hline & Self-Improvement & 4.75 & 0.32 & Very High \\
\hline Legends: & $1.00-1.79$ & Very Low & $3.40-4.19$ & High & \\
& $1.80-2.59$ & Low & $4.20-5.00$ & Very High & \\
& $2.60-3.39$ & Average & & &
\end{tabular}

Table 2 showed that the drug reformists believed that they benefit with a "very high" degree from all the program activities provided to them by the Bahay Pagbabago ni Apong Pilar.

To further assess if there are differences in the drug reformists' attitude towards the formation house's activities and perceived self-improvement between females and males, the Mann-Whitney U test, a nonparametric measure, was utilized as indicated below: 
Table 3.

Test of difference between the drug reformists' attitude towards the formation house's activities and perceived selfimprovement in terms of sex.

\begin{tabular}{llcrrr}
\hline Ranks & Gender & N & Mean Rank & Mann-Whitney U & Sig. value \\
\hline Sports & Male & 24 & 14.17 & 32.00 & 0.756 \\
& Female & 3 & 12.67 & & \\
& Total & 27 & & & \\
\hline Livelihood & Male & 24 & 14.46 & & 0.395 \\
& Female & 3 & 10.33 & 25.00 & \\
& Total & 27 & & & 0.486 \\
Spiritual & Male & 24 & 14.38 & & \\
& Female & 3 & 11 & 33.50 & 0.844 \\
& Total & 27 & & & \\
\hline Self-Improvement & Male & 24 & 13.9 & & \\
& Female & 3 & 14.83 & & \\
& Total & 27 & & & \\
\end{tabular}

$p$ value $<0.05$ level

The table shows that both the male and female respondent reformists did not significantly differ in their attitude in all the three formation house activities at sig. $>0.05$. This means that even if all the male respondents obtained a higher mean rank than the female across the three activities, the data is not enough to support a significant difference. Likewise, no difference in their self-improvement was also noted when grouped according to gender at $\mathrm{U}(\mathrm{N}=27)=33.50$, sig. $=0.844$, where sig. $>0.05$.

Furthermore, to assess if there are differences in the drug reformists' attitude towards the formation house's activities and perceived self-improvement when grouped in terms of age, Kruskal-Wallis $\mathrm{H}$ Test, a non-parametric measure was utilized as indicated below:

Table 4.

Test of difference between the drug reformists' attitude towards the formation house's activities and perceived selfimprovement in terms of age.

\begin{tabular}{|c|c|c|c|c|c|c|}
\hline & Age & $\mathbf{N}$ & Mean Rank & Chi-Square & DF & sig. \\
\hline \multirow[t]{4}{*}{ Sports } & Below 30 years old & 8 & 11.44 & 4.345 & 2 & 0.114 \\
\hline & 31 to 40 years old & 12 & 12.63 & & & \\
\hline & Above 40 years old & 7 & 19.29 & & & \\
\hline & Total & 27 & & & & \\
\hline \multirow[t]{4}{*}{ Livelihood } & Below 30 years old & 8 & 9.94 & 6.589 & 2 & $0.037^{*}$ \\
\hline & 31 to 40 years old & 12 & 13.08 & & & \\
\hline & Above 40 years old & 7 & 20.21 & & & \\
\hline & Total & 27 & & & & \\
\hline \multirow[t]{4}{*}{ Spiritual } & Below 30 years old & 8 & 10.88 & 4.993 & 2 & 0.082 \\
\hline & 31 to 40 years old & 12 & 12.83 & & & \\
\hline & Above 40 years old & 7 & 19.57 & & & \\
\hline & Total & 27 & & & & \\
\hline Improvement & Below 30 years old & 8 & 6.38 & 13.573 & 2 & $0.001^{* *}$ \\
\hline $170-176$ & & & & http://journ & .uinjkt. & $\mathrm{d} /$ index.php \\
\hline
\end{tabular}


TAZKIYA (Journalof Psychology), 9(2), 2021

\begin{tabular}{lrr}
31 to 40 years old & 12 & 15.00 \\
Above 40 years old & 7 & 21.00 \\
Total & 27 & \\
\hline
\end{tabular}

$p$ value $<0.05$ level

Table 4 shows a significant difference in their attitude towards Livelihood activities when grouped according to age at Chi2 $(2)=6.589$, sig. $=0.037^{*}$, were sig. $<0.05$, with a mean rank livelihood score of 20.21 for those above 40 years old, 13.08 for 31 to 40 years old, and 9.94 for those below 30 . Furthermore, Tukey's post hoc analysis suggests that those above 40 years have significantly rated higher than those below 30. This means that the higher age range is more inclined to have higher approval for livelihood activities than the youngest age range. The decision then is to reject the null hypothesis and accept the null that there are at least two age ranges that significantly differ in their attitude towards livelihood activities. In contrast, both their attitude towards sports and spiritual activity did not yield any differences in age at sig. > 0.05.

Further, table 4 shows a significant difference in their perceived self-improvement during their stay in the reformation house when grouped according to age at Chi2 $(2)=13.573$, sig. $=0.001^{* *}$, were sig. < 0.01 , with a mean rank livelihood score of 21.00 for those above 40 years old, 15.00 for 31 to 40 years old, and 6.38 for those below 30. In addition, post hoc analysis using Tukey affirms that those who are above 40 years have significantly rated higher than the other age ranges. This means that the higher age range is more likely to have higher self-improvement than the younger age ranges.

Moreover, to assess if there is a correlation between the drug reformists' perceived self-improvement and their attitude towards formation house's activities, Spearman Rho, a non-parametric measure, was utilized as indicated below:

Table 5.

Correlation between the drug reformists' perceived self-improvement and their attitude towards formation house's activities.

\section{Correlations}

\begin{tabular}{lcccc} 
Spearman's rho & Improvement & Sports & Livelihood & Spiritual \\
\hline Self-Improvement & 1 & $.428^{*}$ & $.608^{* *}$ & $.587^{* *}$ \\
\hline Sportsfest & 1 & $.879^{* *}$ & $.842^{* *}$ \\
Gardening/Livelihood & & & 1 & $.892^{* *}$ \\
Spiritual & & & & 1 \\
\hline
\end{tabular}

* Correlation is significant at the 0.05 level (2-tailed).

** Correlation is significant at the 0.01 level (2-tailed).

Table 5 shows a significant relationship between the respondent reformists' perceived selfimprovement and their attitude towards implementing house activities. $<0.05$. Specifically, their attitude towards livelihood activities and their Self-Improvement significantly moderately correlates at rho $(27)=$ $0.608^{* *}$ is sig. is $<0.01$. This means that a positive increase in their attitude towards the livelihood activities of the formation house would yield to a corresponding increase in their self-improvement. Likewise, spiritual activities also significantly moderately correlate with their self-improvement at rho $(27)=0.587^{* *}$, were sig. $<0.01$. This shows that the higher their involvement in spiritual activities, the more likely they would have a higher chance of improving inside the formation house. Lastly, sports activities also significantly correlate with their self-improvement at rho $(27)=0.428^{*}$, were sig. $<0.05$. This suggests that engaging in sports can more likely result in further self-improvement. 
TAZKIYA (Journalof Psychology), 9(2), 2021

\section{Qualitative Phase}

The following are the results of the thematic analysis extracted from the various focused-group discussions conducted with the drug reformists of the Bahay Pagbabago ni Apong Pilar:

Finding a higher purpose and deeper meaning in life. This theme is illuminated through spiritually uplifting undertakings that the formation center is providing. Their spiritual activities seem to have a good impact on the reformists: ...napapalapit kami sa isa't is at sa Diyos... Opo basta nandyan ang Panginoon. This spiritual development they have learned from the center's formation program can be observed from their everyday activities: Siguro po yung pag bago kami kumain, nagdadasal po kami tapos bago kami matulog, araw-araw nagsisimba. Of note, even though they have imbibed spiritual practice in their everyday lives ever since they entered the program, they acknowledge that personal decision over one's life especially those that relates to their illegal drug use still matters: nasa tao naman po kasi yan e kahit na anong gawin mo kung wala sayo ang pagbabago hindi mo makakamtan sa sarili mo yun kaya nasa tao lang din yun. However, of the numerous benefits the center has imparted on them, it is the self-knowledge that bears one of the heaviest:

Kasi po dati puro barkada, minsan yung sarili mo napapabayaan mo na..yung iniintindi ko lang yung barkada pag nagwawala kaya masasabi kong dito ko nalaman yung pagpapahalaga ko sa sarili ko, kasi dati wala lang kahit anong mangyari sayo.. ayun dito ko nalaman yung pagpapahalaga sa sarili saka sa pamilya.

Additionally, they seem to have a good grasp of the essence of the center's formation program: ano sagipin po siguro sir, sa kasalanan naming mga nagawa...Para po makilala ang Diyos... Para makapagbago sir... Ilayo sa bisyo sir. Beyond their gain, they appraised their experience as even benefiting their own family:

Para po siguro yung pagiging ama po namin sa mga pamilya namin mas maging $100 \%$ na po kasi dati po parang may kahati pa sya e kumbaga yung bisyo naming, hindi naming masabi na 100\% kami sa pamilya e kasi kahati naming yung sa bisyo..siguro po paglabas po namin sa bahay pagbabago na ito, yung bisyo naming na yun parang itatanim po namin yun sa loob ng simbahan na ïwanan po na namin yung bisyo na yun..yung iniisip kasi namin yung sa pamilya at sa Panginoong Jesucristo.

At the outset, what matters the most to them is how their newly found meaning in life had gained a higher purpose: Sir ako po ano, hindi importante yung pangalan na nasa list, ang importante po nun nakilala naming yung sa Taas na nailapit po kami sa Kanya, yun po yung pinaka. Another reformist also stressed the importance of knowing the Almighty and the importance of faith in Him: nun po hindi po kami natatakot sa Diyos, ngayon po takot na takot po parang kasi po nakilala namin sya ng lubos, kung pano nya tayo ginawa.

Having family-oriented treatment. Arguably one of the most flourishing interpersonal approaches especially in the Filipino value system, treating someone afflicted with something terrible like a family member eases one's feeling and thus contributing to their betterment along the way. This seems to be of truth among the drug reformists in the center; making them feel nothing less of their humanity indeed contributes to something of great importance for them even how little they may seem:

Sa ano po sir, sa pagseserve ng pagkain, pangalawa yung pag sa medical check-up namin sa katawan hindi po kami napapabayaan sa kung ano po yung nararamdaman namin, binibigyan po kami ng mga gamot basta magsabi lang po kami kung ano po yung nararamdaman po

This family-oriented treatment even treats them like a real family member and not an outcast of the society or its rejects: yun nga po yung sabi nila mauuna po kaming kumain bago sila, kung wala silang matitirang pagkain di po sila kakain basta makakain lang po kami. Hence, the volunteer-facilitators act like parents and they are their children. This also remains true when disciplining them whenever they have committed mistakes or mishaps: ah siguro pagka meron kaming yung mga konting pagkakamali siguro po tinutuwid nila sa mga pagkakamali naming na... sinasabihan po kami ng maganda para. This gave them a sense of importance instrumental to their rehabilitation: dito po hindi kami trinatratong mga adik, anak ang pakikitungo nila sa amin, kaya po masarap sa pakiramdam... Mahihiya ka nalang na hindi umayos at sumunod, kasi ikaw pa ang uunahin nila para maging okay ka lang. 
Having holistic and dynamic activities. These are programs of the center that focus on the developmental facets like livelihood activities, sports fest, gardening, and even focused-group sharing. Someone had stressed: sa pamamagitan ng sports at pag-attend ng klase..ayun naglalaro..ngayon aah ano..sa sarili ko na..kahit na po hindi po ako natuto at least nakasali ako sa palaro. Even though this could be just a sort of fun, learning can have a lifelong impact and is still imparted. The same can also be said to the livelihood educational programs that are given to them:

Sir, gumagawa po ng ano..longganisa tsaka po yung tinuro po kasi samin yung livelihood program yung paggagawa ng longganisa sir e tsaka po yung tocino, yun po... Oo paglabas po namin tas pwede po naming gawing business... At saka po yung pagmamassage therapy po.

Similar to this, gardening is also fun-filled, fulfilling, and therapeutic as well. This can be observed in the greenery in the center's surroundings. They are also often invited to sing as the Church's choir during Sunday masses and special occasions. This serves as a great way to boost their self-confidence and to change the public's view and opinion of them as drug reformists:

Tsaka po dito parang yung naexpose po kami sa tao na yung dati. kahit na yung pangit ang boses naming talagang nagpupursige kaming kumanta kasi dati kakanta kang mag-isa parang nakakahiya pero pagka group madami kami parang nabubuhayan lumalakas ang loob mo na kumanta kahit sintunado ka di ka po mahihiyang maharap sa tao na ganun,

Additional life skill they have gained from holistic activities the center is providing is the ability to express themselves more eloquently and face people with enough confidence despite their experience: yung pagshasharing sir, opo dati po hindi po kami makapagsalita, nahihiya ngayon kaya na naming magsharing at humarap sa ibang mga tao. This development and improvement are not utterly drastic, however.

Putting all things they learned from the formation center together, they seem to internally understand that it takes efforts and time to complete the formative and rehabilitative process:

Siguro po nabubuo po sya nung mula nung umpisa hanggang sa ngayon po yung napupuno na po sya, nabubuo po paunti-unti yan.. hindi naman po kasi natin mabigla na bukas buo agad tayo buo agad? Hindi...yung arawaraw na nagkaroon kami ng kaalaman unti-unti nabubuo sarili namin sa araw-araw na pakikisalamuha.

Along the way of their successful journey towards rehabilitation, they have gained appreciation of the love of their family for them which serve as a buffer to their desire to further engage in illegal drug use: ngayon mo naramdaman sobrang pagmamahal sayo...ngayon mo nararamdaman na sobrang mahal na mahal mo sila...mahalaga ka pala sa kanila. However, in terms of the factors that need improvement on the existing program of the center, the reformist seem to have a very little to suggest:

Meron po..yung sa attendance sir. Dapat diba sir pag nakaduty ka, dapat aware ka dun sa ano mo sa trabaho mo talaga. Kasi po minsan madami rin yung mga staff ditto matataas hinahanap yung ibang facilitator kasi minsan nagpapractice wala sila, nagkukulang sila sa oras... Nandun po dapat sila hindi yung syempre para pag yung humawak po ng ano nila.

Overall, the drug reformists have shown considerable interest in the formation house's activities for their rehabilitation. Their engagement with the program's activities successfully focuses their attention on transforming themselves and diverting their previous substance use with productivity. Moreover, the core description of their perspectives with the activities center on the learning that they have gained to achieve a better sense of self. Thus, the drug reformists perceived the activities as a tool for improving themselves into better individuals that ultimately benefit them and their families.

In particular, spiritual activities paved the way into a positive outlook in life, giving hope and rediscovering their dignity, which was apparent in other studies (see Paal et al., 2015; Chiu et al., 2004; Galek et al., 2005). These insights are the foundation of their initiative to change and start a life with a deeper purpose and meaning by finding God and themselves. Also, one thing they found interesting with the program activities is the sense of camaraderie. The activities provided a venue to get genuinely involved 
with people and develop relationships. Hence, giving them a desire to provide a helping hand and improve their social skills.

However, although the program has shown positive results and is evaluated to be successful, some areas could be improved. For example, sometimes, the reformists are not enthused about joining the activities, as it seems they are bored or uninterested in daily activities. Moreover, given two months in the formation center with programmed daily activities, the reformists seem to diminish their interest to engage in more activities. Also, as opposed to their very positive responses on the different activities that provided learning and growth, the reformists express average learning only regarding acquiring knowledge and information about illegal drugs. Hence, incorporating psychologically-oriented activity programs to deepen their appreciation and understanding would be a proactive approach to further improving their rehabilitation experiences in Bahay Pagbabago ni Apong Pilar.

\section{Conclusion}

Based on the data gathered by the study, the following conclusions are hereby made:

1. The Bahay Pagbabago ni Apong Pilar, as a Dangerous Drugs Board recognized shelter, seems to have generally an effective formation program for drug reformists.

2. The shelter's sports, livelihood, and sports programs seemed to successfully bridge their goals to develop formative capacities among their clients to combat the debilitating effects of illegal drug use successfully.

3. Based exclusively on the reformists' perspectives, additional factors that might lead to a successful formation and rehabilitation program includes, but not limited to: (a) finding a higher purpose and deeper meaning in life through spiritually uplifting undertakings; (2) having family-oriented treatment, making them feel nothing less of their humanity; and (3) having holistic and dynamic activities, those that focus on the developmental facets. suggested:

Given the results of the study and its implications, the following recommendations are hereby

1. The volunteer facilitators should be more committed to their time schedules in facilitating set activities or programs. Though it is fully understood that this matter is provided entirely voluntarily, needless to the point that every facilitator has their schedules and needs they have to attend to, the reformists pointed out that this time-related concern is the only point for improvement ever observed.

2. Capability-building training should be provided for the volunteer facilitators to equip them with the necessary technical knowledge on facilitating formative and rehabilitative activities essential for the overall recovery of the reformists. The Psychological Association of the Philippines, Inc. (PAP) training module on the Katatagan Kontra Droga sa Kumonidad (KKDK) is exemplary material and must be given enough attention.

3. Psychological training for the reformists must also be a part of the overall formation program of the shelter. This should include, but not be limited to, structured personality development courses.

4. Adding ice-breakers to the program activities could help fight diminishing interest and rekindle enthusiasm on their activity engagement. For facilitators, having more verbal engagement with the participants during activities could encourage participation and decrease boredom from the reformists.

5. Establishing a professional grooming program that will train drug reformists to relearn proper workplace behaviors to gain a positive impression and respect is highly beneficial. It is also a part of changing how the reformists think of themselves and retake part as a member of the society. The 
facilitators should also provide practical tips and guidance on facing certain facets of this program, such as job interview questions, professional appearance, and communication skills.

\section{References}

Chandler, C. K., Holden, J. M., \& Kolander, C. A. (1992). Counseling for spiritual wellness: Theory and practice. Journal of Counseling \& Development, 71(2), 168-175. https://doi.org/10.1002/j.15566676.1992.tb02193.x

Chiu, L., Emblen, J. D., Hofwegen L.V., Sawatzky, R., \& Meyerhoff, H., (2004). An integrative review of the concept of spirituality in the health sciences. http://citeseerx.ist.psu.edu/viewdoc/download?doi=10.1.1.820.5391\&rep=rep1\&type=pdf

Dangerous Drugs Board (DDB). (2015). Philippine National Anti-Drug Plan of Action (NADPA) 20152020. https://www.ddb.gov.ph/images/NADPA 2015-2020 final draft.pdf

Eck, B. E. (2002). An exploration of the therapeutic use of spiritual disciplines in clinical practice. https://brainmass.com/file/287420/An+exploration+of+the+Therapeutic+Use+of+Spiritual+Dis ciplines+in + CLinical+practice + Journal+review $+2 . p d f$

Galek, K., Flannelly, K.J., Vane, A., \& Galek, R. M., (2005). Assessing a patient's spiritual needs. A comprehensive instrument. http://citeseerx.ist.psu.edu/viewdoc/download?doi=10.1.1.484.2415\&rep=rep1\&type=pdf

Grandisson, M., Thibeault, R., Hebert, M., \& Templeton, A. (2014). Community-based rehabilitation programme evaluations: lessons learned in the field. http://dcidj.org/article/view/240

Haque, A. (2000). Psychology and religion: Two approaches to positive mental health. https://s3.amazonaws.com/academia.edu.documents/31788916/483-1124-1-PB.pdf

Hoffman, K. R., (2016). Developing a faith-based early intervention program for adults with alcohol and drug issues. Retrieved from 15 May 2018 from http://agts.edu/wpcontent/uploads/2017/07/24i_Hoffman.pdf

Leahy, M. J., Thielsen, V. A., Millington, M. J., Austin, B., \& Fleming A. (2009). Quality assurance and program evaluations: Terms, models, and applications. Journal of Rehabilitation Administration, 33(2), 69-82.

Miller, W. R., Forcehimes, A., O'Leary, M., \& Lanoue, M.D., (2009). Spiritual Direction in Addiction treatment: Two clinical trials. Retrieved on 15 May 2018 from https://www.ncbi.nlm.nih.gov/pmc/articles/PMC2600849/

Paal, P., Helo, Y., Frick, E. (2015). Spiritual care training provided to healthcare professionals: A systematic review. Journal of Pastoral Care and Counseling (69) 1. https://doi.org/10.1177/1542305015572955

Poll, J. B., \& Smith, T. B., (2003). The Spiritual Self: Toward a Conceptualization of Spiritual Identity

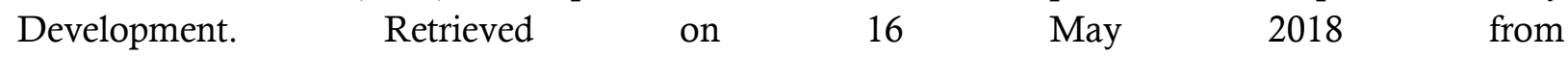
https://scholarsarchive.byu.edu/cgi/viewcontent.cgi?article=3048\&context=facpub

Ramos, S. (2017). Mending broken wings: A budding answer to the philippines' struggle with addiction and its treatment. http://www.ifngo2017.org/wp-content/uploads/2012/07/PLENARY-SESSION-2Teresita-Castillo_Mending-Broken-Wings-ppt.pdf 
Rush, B. (2003). The evaluation of treatment services and systems of substance use disorders. $R$. Psiquiatr. R.S., 25(3), 393-411.

Sharpe, G. (2011). A review of program theory and theory-based evaluations. American International Journal of Contemporary Research, 1(3), 72-75.

United Nations Office on Drugs and Crime (2003). Drug abuse treatment and rehabilitation: A practical planning and implementation guide. https://www.unodc.org/docs/treatment/Guide_E.pdf

Whitley, R. \& Drake, R., (2010). Recovery: A dimensional approach. https://ps.psychiatryonline.org/doi/full/10.1176/ps.2010.61.12.1248

World Council of Churches (2001). A breakfast to break barriers. https://www.oikoumene.org/en/what-wedo/health-and-healing/con175.pdf

$\mathrm{Wu}, \mathrm{L}$. T. (2010). Substance abuse and rehabilitation: responding to the global burden of diseases attributable to substance abuse. Substance abuse and rehabilitation, (1), 5. 